DOI: 10.14807/ijmp.v11i3.930

\title{
ABOUT THE INTERNAL COMBUSTION ENGINES FORCES
}

\author{
Relly Victoria Virgil Petrescu \\ IFToMM, Romania \\ E-mail: rvvpetrescu@gmail.com \\ Florian Ion Tiberiu Petrescu \\ IFToMM, Romania \\ E-mail: fitpetrescu@gmail.com
}

Submission: $12 / 10 / 2018$

Revision: 2/8/2019

Accept: 9/19/2019

\section{ABSTRACT}

The paper presents an algorithm to set the parameters of the dynamics of the classic mechanism the main of internal combustion. It shows the distribution of the forces (on the main mechanism of the engine) on engines with internal combustion. Dynamic, the gears can be distributed in the same way as forces. Practically, in the dynamic regimes, the velocities have the same synchronization as forces. The method shall be applied separately for two distinct situations: when the engine is working on a compressor and in the system of the motor. For the two individual cases, two independent formulae are obtained for the dynamic cinematic forces (gearbox). The calculations shall be made for an engine with a single cylinder. The change of speed in the dynamics feels like a variation of the angular speed of the engine. It is more difficult to be taken into account (theoretically) effect on an engine with several cylinders.

Keywords: Kinematics; Forces; Velocities; Powers; Engines; Efficiency; Geometry; Synthesis; Yield. 
ISSN: $2236-269 X$

DOI: $10.14807 /$ ijmp.v11i3.930

\section{INTRODUCTION}

Today we are at a crossroads in terms of how the transports will be carried out in the future. Those who see a sudden change are insulting because such changes are made slowly, taking into account the continuous improvement of new technologies as well as the financial possibilities to change old production lines and sometimes a whole factory.

Changes began massively with automation and robotization, which overcame the industrialization of old mechanization. The electronics, software, digitization, computer science, the net also bring about big, permanent changes, fast and sometimes so hard it's hard to keep up with them. Robots so initially blamed helped us to live better, to work less, easier, safer, healthier, with breaks and vacations, but also with beautiful weekends.

They are now doing our hard, tiring, repetitive work in toxic, unfriendly, chemical, radiochemical, aquatic environments in the cosmos, thus avoiding many evils, protecting us, helping us, letting people work lighter and more beautiful, such as coordination, design, research.

In the field of transport, we have been helped for two hundred years by thermal engines, which even though still old we still wear today. How will it be in the future? A question that no one can answer right now. Much of public transport has already been electrified since 19701980, due to the major energy crisis of that period. But if about $70 \%$ of the railway transport (trains, trams, trolleybuses, subways) passed on electric, yet there are massive transports with ships, air and road which are still being used with thermal motorization, mostly for engines internal combustion, gasoline or diesel, most of which are four-stroke.

If we consider only personal cars that already exceed one billion and are almost all equipped with internal combustion engines, and every year this park is still augmented by about one 100 millions new personal cars, we can easily see that fact any past or current electrification attempt is just a minor try. Vessels consume a very large amount of fuel and all use only thermal engines today.

The same happens with aviation in general, and electrification attempts are also minor, to some small, light aircraft, and some helicopters and drones. The electrification attempts on buses have managed to bring some tens of thousands of electric buses into operation, as well as those with liquid gas (even more), but in total, they represent nothing in the fleet of over a billion cars in circulation. 
INDEPENDENT JOURNAL OF MANAGEMENT \& PRODUCTION (IJM\&P)

http://www.ijmp.jor.br

v. 11, n. 3, May-June 2020

ISSN: $2236-269 X$

DOI: $10.14807 /$ ijmp.v11i3.930

When talking about hybrid cars we generally refer to hybrid vehicles with a hybrid transmission and not to hybrid engines. Hybrid engines on motor vehicles are rare and their percentage has remained insignificant.

There is talk of about twenty years of free energy, and different schemes are being developed to get it in much better ways. Why then do the magnetic or electromagnetic motors still not appear on the means of transport? The major problem here is a techno-financial one because these engines are not yet reliable, they do not have a life long enough to cushion the costs of their production, and the magnetic materials can degrade over the course of their operation. On the other hand, this is also the operational safety, which is vital for aircraft, and we could not bet on such engines if it would have to repair them on their return if they would give up during the flight, because the return with them would no longer be possible.

The future will be electric, but it will take some time with its implementation.

An interesting solution, which has already succeeded in imposing itself on the car market, is that of hydrogen cars, a future solution, but even if it has occupied a larger segment in total, it is also insignificant, but it still plays an important role in further development of transport.

In order to remove hydrogen from the water directly on the vehicle, we still have to expect sometimes even if the possible solutions are known today because there is no emphasis on this important scientific research part from which energy from water can be extracted. Today's modern methods can dissociate water with low energy consumption, using platinum and gold as catalysts, a medium with ultraviolet radiation intensity control and the forced passage of pressure water through minicells using nanotechnologies.

Then the hydrogen is burned with oxygen, resulting in water and more energy than the one used for dissociation, so water can become an energy storage medium. The cycle can then be used infinitely without losses and without pollution. The method is not yet desirable to be used even though it would only bring enormous benefits to shipbuilding, reducing pollution and massive use of oil, polluting, costly, unfriendly.

It is for the first time in the history of mankind when large companies begin to prepare for the construction of dynamic, high quality, high quality industrial electric cars, industrial scale. Several important Auto-Concerns have already dealt with this, but Volkswagen and Ford have already begun major changes to this. Years to come will bring massive production of fully electrified personal cars. 
DOI: 10.14807/ijmp.v11i3.930

Even so, a fleet of over a billion vehicles equipped with internal combustion engines can not be removed overnight, so research in that field still needs to continue for a while, and any innovative solution will still be a solid link in diminishing consumption of classical fuels, pollution and noxes. In this context, the present paper is also written (ANTONESCU; PETRESCU, 1985; ANTONESCU; PETRESCU, 1989; ANTONESCU et al., 1985a; ANTONESCU et al., 1985b; ANTONESCU et al., 1986; ANTONESCU et al., 1987; ANTONESCU et al., 1988; ANTONESCU et al., 1994; ANTONESCU et al., 1997; ANTONESCU et al., 2000a; ANTONESCU et al., 2000b; ANTONESCU et al., 2001; ATEFI et al., 2008; AVAEI et al., 2008; AVERSA et al., 2017a; AVERSA et al., 2017b; AVERSA et al., 2017c; AVERSA et al., 2017d; AVERSA et al., 2017e; AVERSA et al., 2016a; AVERSA et al., 2016b; AVERSA et al., 2016c; AVERSA et al., 2016d; AVERSA et al., 2016e; AVERSA et al., 2016f; AVERSA et al., 2016g; AVERSA et al., 2016h; AVERSA et al., 2016i; AVERSA et al., 2016j; AVERSA et al., 2016k; AVERSA et al., 2016l; AVERSA et al., 2016m; AVERSA et al., 2016n; AVERSA et al., 2016o; AZAGA; OTHMAN, 2008; CAO et al., 2013; DONG et al., 2013; EL-TOUS, 2008; COMANESCU, 2010; FRANKLIN, 1930; HE et al., 2013; JOLGAF et al., 2008; KANNAPPAN et al., 2008; LEE, 2013; LIN et al., 2013; LIU et al., 2013; MEENA; RITTIDECH, 2008; MEENA et al., 2008; MIRSAYAR et al., 2017; NG et al., 2008; PADULA et al., 2008; 2013; PERUMAAL; JAWAHAR, 2013; PETRESCU, 2011; PETRESCU, 2015a; PETRESCU, 2015b; PETRESCU; PETRESCU, 1995a; PETRESCU; PETRESCU, 1995b; PETRESCU; PETRESCU, 1997a; PETRESCU; PETRESCU, 1997b; PETRESCU; PETRESCU, 1997c; PETRESCU; PETRESCU, 2000a; PETRESCU; PETRESCU, 2000b; PETRESCU; PETRESCU, 2002a; PETRESCU; PETRESCU, 2002b; PETRESCU; PETRESCU, 2003; PETRESCU; PETRESCU, 2005a; PETRESCU; PETRESCU, 2005b; PETRESCU; PETRESCU, 2005c; PETRESCU; PETRESCU, 2005d; PETRESCU; PETRESCU, 2005e; PETRESCU; PETRESCU, 2011a; PETRESCU; PETRESCU, 2011b; PETRESCU; PETRESCU, 2012a; PETRESCU; PETRESCU, 2012b; PETRESCU; PETRESCU, 2013a; PETRESCU; PETRESCU, 2013b; PETRESCU; PETRESCU, 2016a; PETRESCU; PETRESCU, 2016b; PETRESCU; PETRESCU, 2016c; PETRESCU et al., 2009; PETRESCU et al., 2016; PETRESCU et al., 2017a; PETRESCU et al., 2017b; PETRESCU et al., 2017c; PETRESCU et al., 2017d; PETRESCU et al., 2017e; PETRESCU et al., 2017f; PETRESCU et al., 2017g; PETRESCU et al., 2017h; PETRESCU et al., 2017i; PETRESCU et al., 2017j; PETRESCU et al., 2017k; PETRESCU et al., 2017l; PETRESCU et al., 2017m; PETRESCU et al., 2017n; PETRESCU et al., 2017o; PETRESCU et al., 2017p; PETRESCU et al., 2017q; PETRESCU et al., 2017r; 
DOI: $10.14807 /$ ijmp.v11i3.930

PETRESCU et al., 2017s; PETRESCU et al., 2017t; PETRESCU et al., 2017u; PETRESCU et al., 2017v; PETRESCU et al., 2017w; PETRESCU et al., 2017x; PETRESCU et al., 2017y; PETRESCU et al., 2017z; PETRESCU et al., 2017aa; PETRESCU et al., 2017ab; PETRESCU et al., 2017ac; PETRESCU et al., 2017ad; PETRESCU et al., 2017ae; PETRESCU et al., 2018a; PETRESCU et al., 2018b; PETRESCU et al., 2018c; PETRESCU et al., 2018d; PETRESCU et al., 2018e; PETRESCU et al., 2018f; PETRESCU et al., 2018g; PETRESCU et al., 2018h; PETRESCU et al., 2018i; PETRESCU et al., 2018j; PETRESCU et al., 2018k; PETRESCU et al., 2018l; PETRESCU et al., 2018m; PETRESCU et al., 2018n; POURMAHMOUD, 2008; RAJASEKARAN et al., 2008; SHOJAEEFARD et al., 2008; TAHER et al., 2008; TAVALLAEI; TOUSI, 2008; THEANSUWAN; TRIRATANASIRICHAI, 2008; ZAHEDI et al., 2008; ZULKIFLI et al., 2008).

\section{METHODS AND MATERIALS}

\subsection{Presents the Algorithm for the Otto Engine in Compressor System}

It presents an algorithm to set the parameters of the dynamics of the classic mechanism the main of internal combustion. It shows the distribution of the forces (on the main mechanism of the engine) on engines with internal combustion. Dynamic, the gears can be distributed in the same way as forces. Practically, in the dynamic regimes, the gears have the same synchronization as forces.

The method shall be applied separately for two distinct situations: when the engine is working on a compressor and in the system of the engine. For the two individual cases, two independent formulae are obtained for the dynamic cinematic forces (gearbox). The calculations shall be made for an engine with a single cylinder. It is more difficult to be taken into account (theoretically) effect on engine with several cylinders. Start with the mechanism of the primary engine in the compressor (when the motor mechanism operates the crank, see figure 1). 
DOI: 10.14807/ijmp.v11i3.930

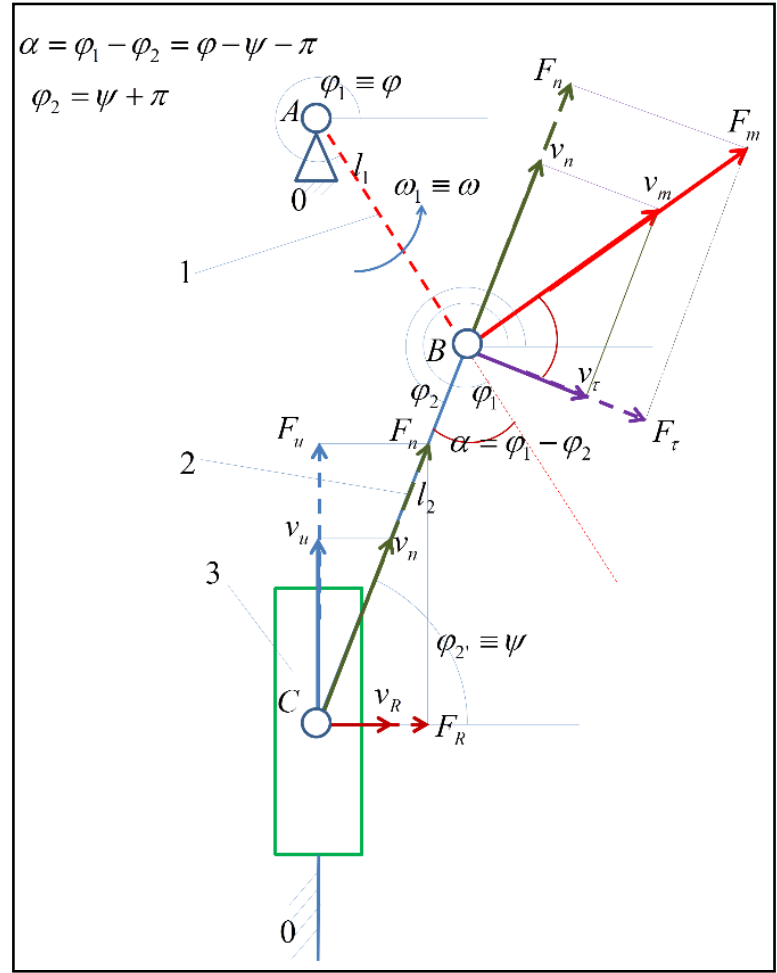

Figure 1: The forces and velocities distribution in engine mechanism, when it is operated of the crank (element 1)

Now we are going to watch forces distribution in this case (figure 1). The motor force $F_{m}$, perpendicular in $B$ on the crank 1, is divided in two components: $F_{n}$ and $F_{\tau}$. The normal force, $F_{n}$, is transmitted along the rod (connecting rod) from point $\mathrm{B}$ to the point $\mathrm{C}$. The tangential force, $\mathrm{F}_{\tau}$, is a rotating force which made the rotation of the connecting rod (element 2). The $F_{n}$ (normal) force from the point $C$ is divided as well in two components: $F_{u}$ and $F_{R}$. The utile force, $F_{u}$, moves the piston, and the radial force, $F_{R}$, press on the cylinder barrel in which guides the piston.

Dynamic, the velocities can be distributed in the same way as forces. Practically, in the dynamic regimes, the velocities have the same timing as the forces: $\mathrm{Vm}$ : is the motor velocity; $\mathrm{V}_{\mathrm{n}}$ : is the normal velocity, which is transmitted along the connecting rod; $\mathrm{v}_{\tau}$ : is the tangential velocity, which produces the rotation of the element; vR: is the radial velocity, who press on the cylinder barrel in which guides the piston (This velocity produces a radial vibration); vu: The utile velocity, moves the piston (when the mechanism is in compressor system). We can write the following relations of calculation (1-2) (PETRESCU; PETRESCU, 2005; PETRESCU; PETRESCU, 2011; PETRESCU; PETRESCU, 2013a; PETRESCU; PETRESCU, 2013b; PETRESCU; PETRESCU, 2013c; PETRESCU; PETRESCU, 2013d; 
PETRESCU; PETRESCU, 2014; PETRESCU et al., 2005; PETRESCU, 2012a; PETRESCU, 2012b).

$$
\begin{aligned}
& \left\{\begin{array}{l}
v_{m} \equiv v_{B}=l_{1} \cdot \omega \\
v_{n}=v_{m} \cdot \sin \left(\varphi-\varphi_{2}\right)=v_{m} \cdot \sin (\psi-\varphi) \\
v_{\tau}=v_{m} \cdot \cos \left(\varphi-\varphi_{2}\right)=-v_{m} \cdot \cos (\psi-\varphi) \\
v_{u}=v_{n} \cdot \sin \psi=v_{m} \cdot \sin (\psi-\varphi) \cdot \sin \psi \\
v_{R}=v_{n} \cdot \cos \psi=v_{m} \cdot \sin (\psi-\varphi) \cdot \cos \psi
\end{array}\right. \\
& \int v_{C}^{\text {Din.c }}=v_{u}=l_{1} \cdot \omega \cdot \sin (\psi-\varphi) \cdot \sin \psi \\
& \left\{v_{C}^{\text {Din.c }}=v_{C} \cdot D^{c}=\frac{l_{1} \cdot \omega \cdot \sin (\psi-\varphi)}{\sin \psi} \cdot D^{c} \Rightarrow D^{c}=\sin ^{2} \psi\right. \\
& \Rightarrow w^{c} \equiv \omega^{\text {Din.c }}=\omega \cdot D^{c} ; \quad \dot{D}^{c}=2 \cdot \sin \psi \cdot \cos \psi \cdot \dot{\psi}=\sin 2 \psi \cdot \dot{\psi} \\
& \int \frac{d}{d t}\left[v_{C} \cdot \sin \psi=l_{1} \cdot \omega \cdot \sin (\psi-\varphi)\right] \Rightarrow \\
& \left\{a_{C} \cdot \sin \psi+v_{C} \cdot \cos \psi \cdot \dot{\psi}=l_{1} \cdot \omega \cdot \cos (\psi-\varphi) \cdot(\dot{\psi}-\omega) \Rightarrow\right. \\
& \Rightarrow a_{C}=\frac{l_{1} \cdot \omega \cdot \cos (\psi-\varphi) \cdot(\dot{\psi}-\omega)}{\sin \psi}-\frac{l_{1} \cdot \omega \cdot \sin (\psi-\varphi) \cdot \cos \psi \cdot \dot{\psi}}{\sin ^{2} \psi} \\
& a_{C}^{\text {Din.c }}=\frac{d}{d t}\left(v_{C}^{\text {Din.c }}\right)=\frac{d}{d t}\left(v_{C} \cdot D^{c}\right)=a_{C} \cdot D^{c}+v_{C} \cdot \dot{D}^{c}
\end{aligned}
$$

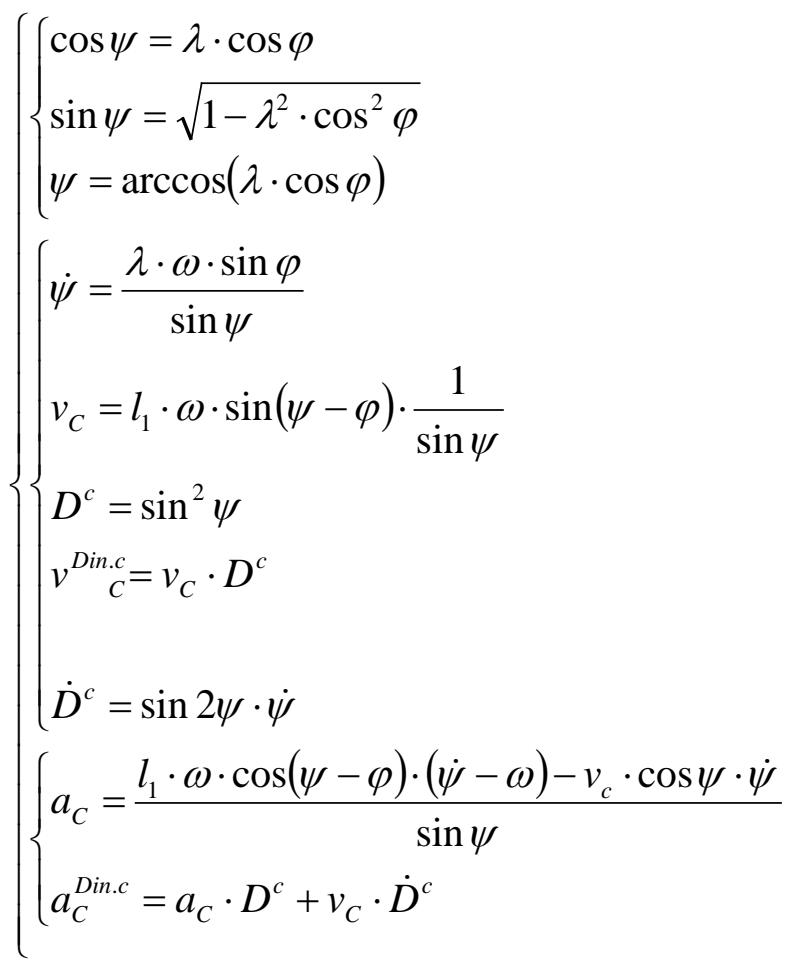

The forces of mechanism can be seen in the Figure 2. 


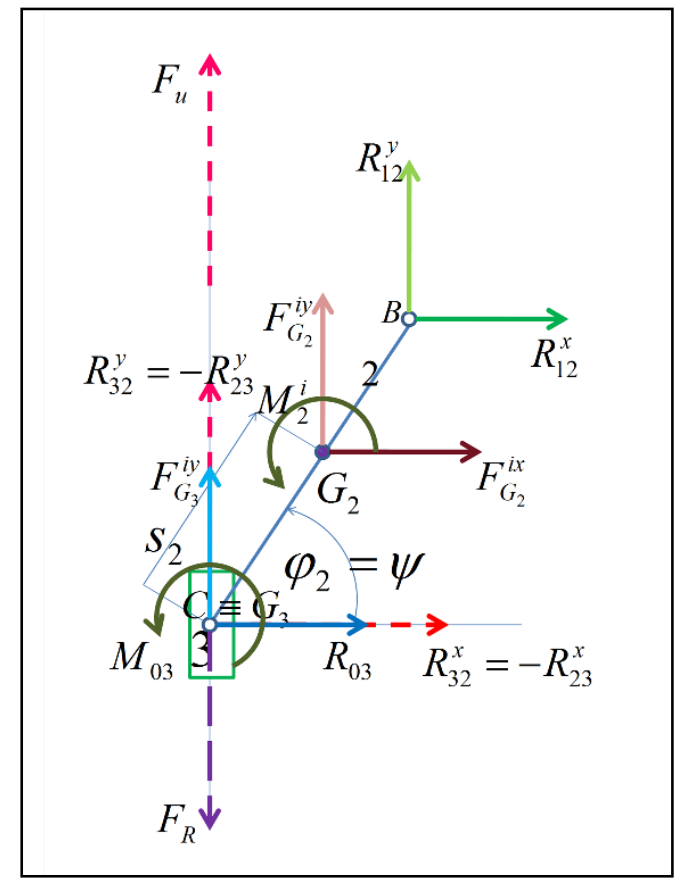

Figure 2: The forces of mechanism, when it is operated from the crank (element 1)

Express motive power through conservation of powers of all the mechanism (system 3) (Petrescu and Petrescu, 2005, 2011, 2013a-d, 2014; Petrescu et al., 2005; Petrescu, 2012a-b).

$$
\begin{aligned}
& \sum P=0 \Rightarrow F_{m} \cdot l_{1} \cdot \omega_{1}+M_{2}^{i} \cdot \omega_{2}+F_{G_{2}}^{i x} \cdot \dot{x}_{G_{2}}+ \\
& +F_{G_{2}}^{i y} \cdot \dot{y}_{G_{2}}+F_{G_{3}}^{i y} \cdot \dot{y}_{G_{3}}+F_{R} \cdot \dot{y}_{C}=0 ; \quad F_{u}=-F_{R} \Rightarrow \\
& \left\{\begin{array}{l}
F_{u}=\frac{F_{m} \cdot l_{1} \cdot \omega_{1}+M_{2}^{i} \cdot \omega_{2}+F_{G_{2}}^{i x} \cdot \dot{x}_{G_{2}}+F_{G_{2}}^{i y} \cdot \dot{y}_{G_{2}}+F_{C}^{i y} \cdot \dot{y}_{C}}{\dot{y}_{C}} \\
F_{u}=F_{m} \cdot \sin \psi \cdot \sin (\psi-\varphi)
\end{array}\right. \\
& \Rightarrow F_{m}=\frac{F_{C}^{i y} \cdot \dot{y}_{C}+M_{2}^{i} \cdot \omega_{2}+F_{G_{2}}^{i x} \cdot \dot{x}_{G_{2}}+F_{G_{2}}^{i y} \cdot \dot{y}_{G_{2}}}{\dot{y}_{C} \cdot \sin \psi \cdot \sin (\psi-\varphi)-l_{1} \cdot \omega_{1}} \\
& M_{m}=F_{m} \cdot l_{1}
\end{aligned}
$$

In the diagram below (figure 3) we compare this new torque with the classic (PETRESCU; PETRESCU， 2005; PETRESCU; PETRESCU， 2011; PETRESCU; PETRESCU, 2013a; PETRESCU; PETRESCU, 2013b; PETRESCU; PETRESCU, 2013c; PETRESCU; PETRESCU, 2013d; PETRESCU; PETRESCU, 2014; PETRESCU et al., 2005; PETRESCU, 2012a; PETRESCU, 2012b). 
DOI: $10.14807 /$ ijmp.v11i3.930

The new torque was determined considering the variation of velocities with forces and forces variation due to velocities (system 3).

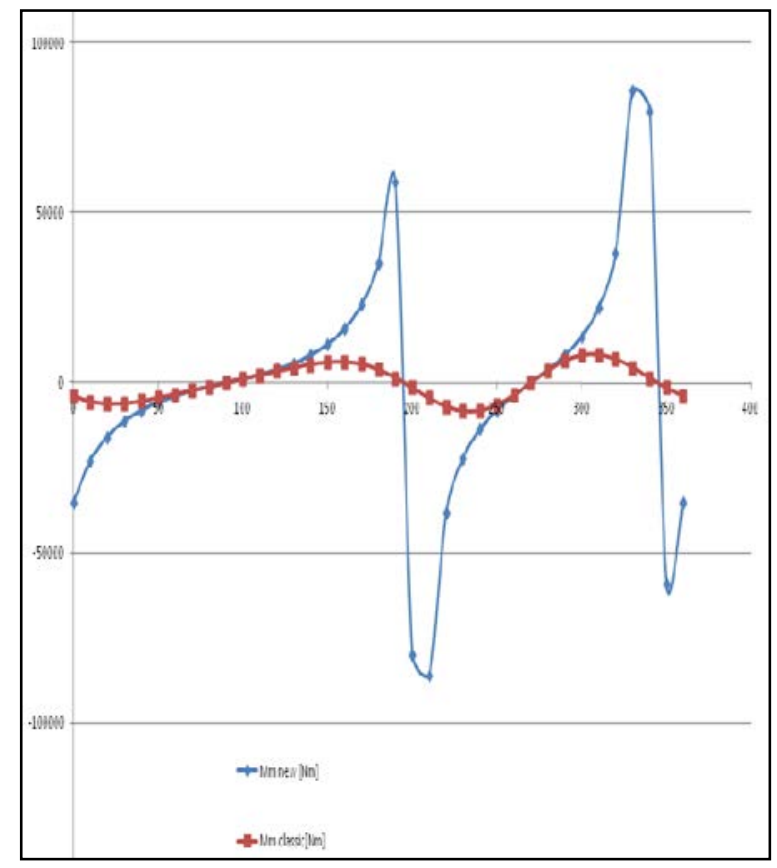

Figure 3: The classical torque and the new torque

\subsection{Presents the Algorithm for the Otto Engine in Motor System}

Now we will look at the main mechanism of the engine in the system with the engine (when the motor mechanism acting on the piston, see figure 4). In this case, useful is one real, be produced by the piston engine (item 3). It should be noted that the drive power from now on the piston is divided in two components, normal and tangential, only a normal part being transmitted through the cone rod to the coupler $\mathrm{B}$, where shall be divided into two other components, $F_{u}$ and $F_{c}$, out of which only useful components is turning the handle while the code by the mills of compression on crank (B) and then on the crank and bearing (A) (PETRESCU; PETRESCU, 2005; PETRESCU; PETRESCU, 2011; PETRESCU; PETRESCU, 2013a; PETRESCU; PETRESCU, 2013b; PETRESCU; PETRESCU, 2013c; PETRESCU; PETRESCU, 2013d; PETRESCU; PETRESCU, 2014; PETRESCU et al., 2005; PETRESCU, 2012a; PETRESCU, 2012b).

Dynamic, the gears can be distributed in the same way as forces. Practically, in the dynamic regimes, the gears have the same synchronization that forces: The $\mathrm{vm}_{\mathrm{m}}$ is the speed of the engine; $\mathrm{v}_{\mathrm{n}}$ : this is the normal speed, which is transmitted along the connecting rod; $\mathrm{v}_{\tau}$ : is the speed of the tangential, which produces rod from rotating (item 2); vc: is the speed of compression and presses the button crank (B) and then on the crank and bearing (A); this speed 
ISSN: 2236-269X

DOI: 10.14807/ijmp.v11i3.930

produces vibrations of bearings; vu: the utile velocity, rotates crank (when the mechanism is in the system with the engine).

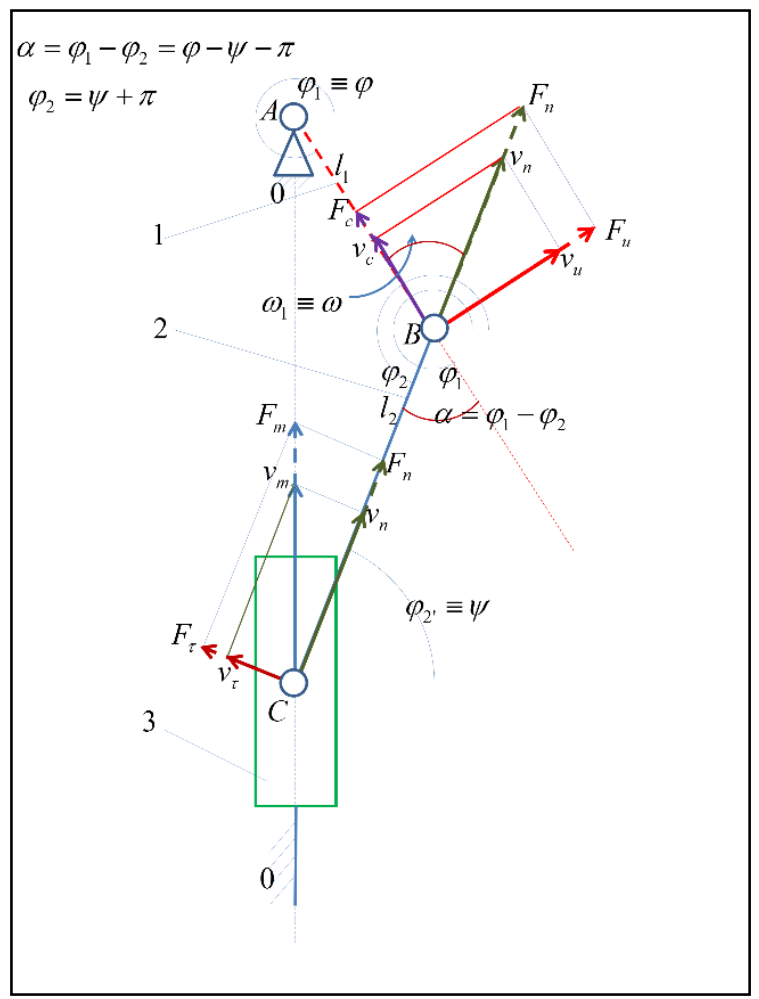

Figure 4: The forces and velocities distribution in engine mechanism, when it is operated of the piston (element 3)

We can write the following relations of calculation (4-5).

$$
\left\{\begin{array}{l}
\left\{\begin{array}{l}
v_{n}=v_{m} \cdot \sin \psi \\
v_{u}=v_{n} \cdot \sin (\psi-\varphi)=v_{m} \cdot \sin \psi \cdot \sin (\psi-\varphi) \\
v_{u}=\frac{l_{1} \cdot \omega \cdot \sin (\psi-\varphi)}{\sin \psi} \cdot \sin \psi \cdot \sin (\psi-\varphi)
\end{array}\right. \\
\left\{\begin{array}{l}
v_{u}=l_{1} \cdot \omega \cdot \sin ^{2}(\psi-\varphi) \equiv v_{B}^{\text {Din.m }} \\
v_{B}^{\text {Din.m }}=v_{B} \cdot D^{m}=l_{1} \cdot \omega \cdot D^{m}
\end{array} \Rightarrow D^{m}=\sin ^{2}(\psi-\varphi)\right. \\
\dot{D}^{m}=\sin 2(\psi-\varphi) \cdot(\dot{\psi}-\omega) \\
\left\{\begin{array}{l}
a_{C}=\frac{l_{1} \cdot \omega \cdot \cos (\psi-\varphi) \cdot(\dot{\psi}-\omega)-v_{c} \cdot \cos \psi \cdot \dot{\psi}}{\sin \psi} \\
a_{C}^{\text {Din.m }}=a_{C} \cdot D^{m}+v_{C} \cdot \dot{D}^{m}
\end{array}\right.
\end{array}\right.
$$


ISSN: $2236-269 X$

DOI: 10.14807/ijmp.v11i3.930

$$
\begin{aligned}
& \left\{\begin{array}{l}
\cos \psi=\lambda \cdot \cos \varphi \\
\sin \psi=\sqrt{1-\lambda^{2} \cdot \cos ^{2} \varphi} \\
\psi=\arccos (\lambda \cdot \cos \varphi)
\end{array}\right. \\
& \dot{\psi}=\frac{\lambda \cdot \omega \cdot \sin \varphi}{\sin \psi} \\
& v_{C}=l_{1} \cdot \omega \cdot \sin (\psi-\varphi) \cdot \frac{1}{\sin \psi} \\
& D^{m}=\sin ^{2}(\psi-\varphi) \\
& v_{C}^{\text {Din.m }}=v_{C} \cdot D^{m} \\
& \dot{D}^{m}=\sin 2(\psi-\varphi) \cdot(\dot{\psi}-\omega) \\
& \left\{\begin{array}{l}
a_{C}=\frac{l_{1} \cdot \omega \cdot \cos (\psi-\varphi) \cdot(\dot{\psi}-\omega)-v_{c} \cdot \cos \psi \cdot \dot{\psi}}{\sin \psi} \\
a_{C}^{\text {Din.m }}=a_{C} \cdot D^{m}+v_{C} \cdot \dot{D}^{m}
\end{array}\right.
\end{aligned}
$$

\section{RESULTS AND DISCUSSION}

The diagrams of velocities and accelerations can be seen in the figures below. In figure 5 it presents the velocities (cinematic and dynamic) in compressor system and in the figure 7 the same velocities in motor system. The acceleration (cinematic and dynamic) can be seen in the figure 6 (compressor system) and 8 (motor system); $(\lambda=0.33 ; n=3000[\mathrm{rpm}])$.

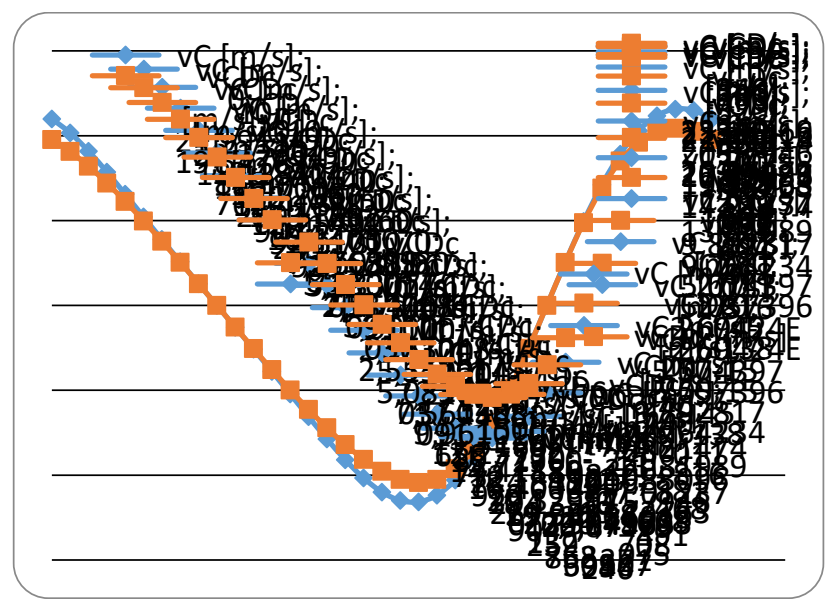

Figure 5: The cinematic and dynamic velocities to a heat mono cylinder engine, in compressor system 
ISSN: 2236-269X

DOI: $10.14807 /$ ijmp.v11i3.930

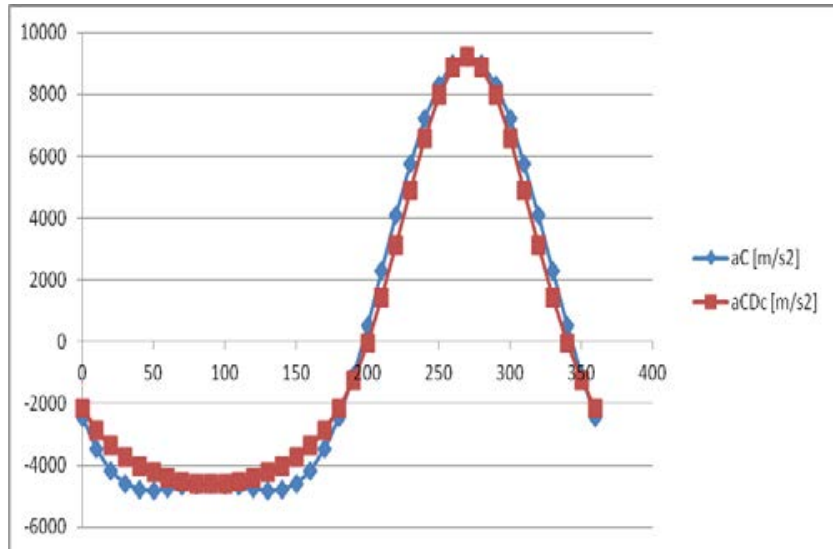

Figure 6: The cinematic and dynamic accelerations to a heat mono cylinder engine, in compressor system

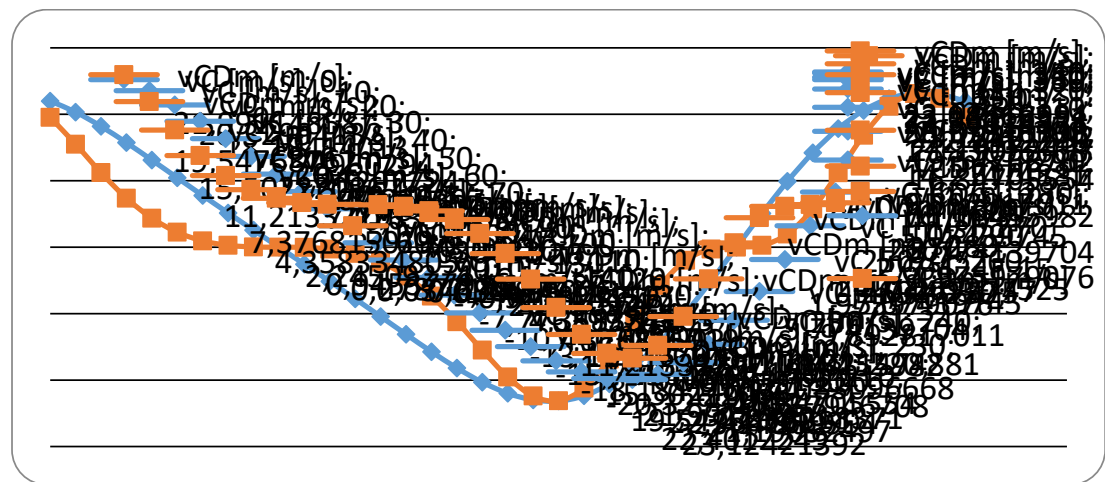

Figure 7: The cinematic and dynamic velocities to a heat mono cylinder engine, in motor system

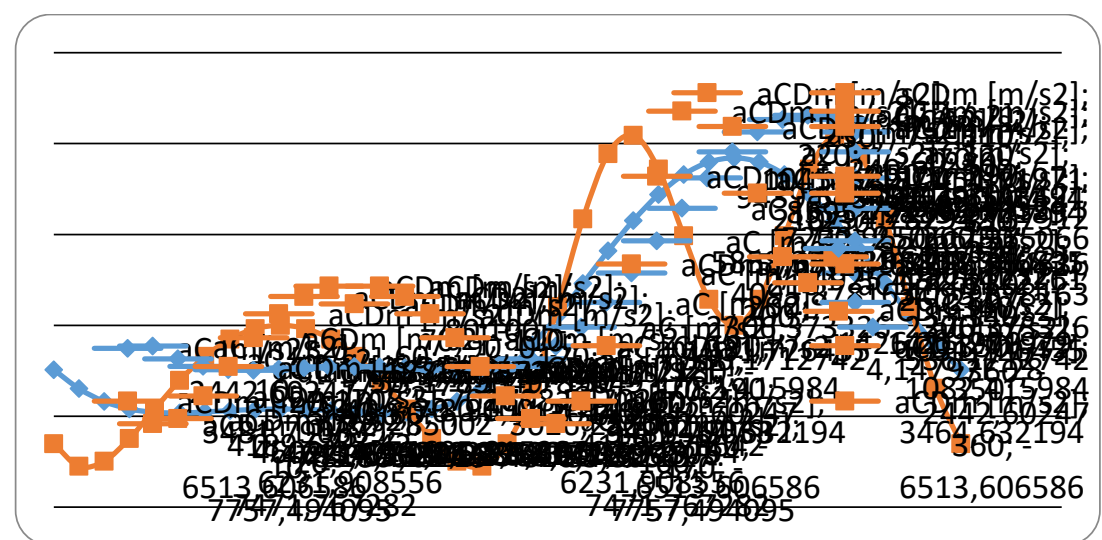

Figure 8: The cinematic and dynamic accelerations to a heat mono cylinder engine, in motor system

It presents an algorithm to set the parameters of the dynamics of the classic mechanism the main of internal combustion. It shows the distribution of the forces (on the main mechanism of the engine) on engines with internal combustion (AMORESANO et al., 2013). Dynamic, the gears can be distributed in the same way as forces. Practically, in the dynamic regimes, the gears have the same synchronization as forces (HRONES, 1948). 
DOI: 10.14807/ijmp.v11i3.930

The method shall be applied separately for two distinct situations: when the engine is working on a compressor and in the system of the engine. For the two individual cases, two independent formulae are obtained for the dynamic cinematic forces (gearbox). The calculations shall be made for an engine with a single cylinder.

It is more difficult to be taken into account (theoretically) effect on engine with several cylinders. Start with the mechanism of the primary engine in the compressor (when the motor mechanism operates the crank, see figure 1). Now we will look at the main mechanism of the engine in the system with the engine (when the motor mechanism acting on the piston, see fig. 4), (PETRESCU; PETRESCU, 2005; PETRESCU; PETRESCU, 2011; PETRESCU; PETRESCU, 2013a; PETRESCU; PETRESCU, 2013b; PETRESCU; PETRESCU, 2013c; PETRESCU; PETRESCU, 2013d; PETRESCU; PETRESCU, 2014; PETRESCU et al., 2005; PETRESCU, 2012a; PETRESCU, 2012b).

In this case, useful is one real, be produced by the piston engine (item 3).

It should be noted that the drive power from now on the piston is divided in two components, normal and tangential, only a normal part being transmitted through the cone rod to the coupler $\mathrm{B}$, where shall be divided into two other components, $\mathrm{F}_{\mathrm{u}}$ and $\mathrm{F}_{\mathrm{c}}$, out of which only useful components is turning the handle while the code by the mills of compression on crank (B) and then on the crank and bearing (A), (PETRESCU; PETRESCU, 2005; PETRESCU; PETRESCU, 2011; PETRESCU; PETRESCU, 2013a; PETRESCU; PETRESCU, 2013b; PETRESCU; PETRESCU, 2013c; PETRESCU; PETRESCU, 2013d; PETRESCU; PETRESCU, 2014; PETRESCU et al., 2005; PETRESCU, 2012a; PETRESCU, 2012b).

Dynamic, the gears can be distributed in the same way as forces. Practically, in the dynamic regimes, the gears have the same synchronization that forces: the $\mathrm{vm}_{\mathrm{m}}$ : is the speed of the engine; $\mathrm{v}_{\mathrm{n}}$ : this is the normal speed, which is transmitted along the connecting rod; $\mathrm{v}_{\tau}$ : is the speed of the tangential, which produces rod from rotating (item 2); vc: is the speed of compression and presses the button crank (B) and then on the crank and bearing (A); this speed produces vibrations of bearings; vu: the utile velocity, rotates crank (when the mechanism is in the system with the engine). Internal combustion engines of heat speeds and actual accelerations (in dynamic schemes) are different kinematic that speeds and accelerations (classical). 
DOI: 10.14807/ijmp.v11i3.930

Dynamic, the gears can be distributed in the same way as forces. Practically, in the dynamic regimes, the gears have the same synchronization as forces.

The method shall be applied separately for two distinct situations: when the engine is working on a compressor and in the system of the engine.

Large variations appear in the engine system.

The change of speed in the dynamics feels like a variation of the angular speed of the engine.

The calculations shall be made for an engine with a single cylinder. It is more difficult to be taken into account (theoretically) effect on engine with several cylinders (PETRESCU; PETRESCU, 2005; PETRESCU; PETRESCU, 2011; PETRESCU; PETRESCU, 2013a; PETRESCU; PETRESCU， 2013b; PETRESCU; PETRESCU, 2013c; PETRESCU; PETRESCU, 2013d; PETRESCU; PETRESCU, 2014; PETRESCU et al., 2005; PETRESCU, 2012a; PETRESCU, 2012b).

\section{CONCLUSIONS}

Internal combustion engines of heat speeds and actual accelerations (in dynamic schemes) are different kinematic that speeds and accelerations (classical).

Dynamic, the gears can be distributed in the same way as forces.

Practically, in the dynamic regimes, the gears have the same synchronization as forces.

The method shall be applied separately for two distinct situations: when the engine is working on a compressor and in the system of the engine (ZHU et al., 2007).

Large variations appear in the engine system.

The change of speed in the dynamics feels like a variation of the angular speed of the engine.

The calculations shall be made for an engine with a single cylinder. It is more difficult to be taken into account (theoretically) effect on engine with several cylinders (PETRESCU; PETRESCU, 2005; PETRESCU; PETRESCU, 2011; PETRESCU; PETRESCU, 2013a; PETRESCU; PETRESCU, 2013b; PETRESCU; PETRESCU, 2013c; PETRESCU; PETRESCU, 2013d; PETRESCU; PETRESCU, 2014; PETRESCU et al., 2005; PETRESCU, 2012a; PETRESCU, 2012b).

\section{ACKNOWLEDGEMENT}


DOI: $10.14807 /$ ijmp.v11i3.930

This text was acknowledged and appreciated by Dr. Veturia CHIROIU Honorific member of Technical Sciences Academy of Romania (ASTR) PhD supervisor in Mechanical Engineering.

\section{FUNDING INFORMATION}

Research contract:

1) Research contract: Contract number 36-5-4D/1986 from 24IV1985, beneficiary CNST RO (Romanian National Center for Science and Technology) Improving dynamic mechanisms.

2) Contract research integration. 19-91-3 from 29.03.1991; Beneficiary: MIS; TOPIC: Research on designing mechanisms with bars, cams and gears, with application in industrial robots.

3) Contract research. GR 69/10.05.2007: NURC in 2762; theme 8: Dynamic analysis of mechanisms and manipulators with bars and gears.

4) Labor contract, no. 35/22.01.2013, the UPB, "Stand for reading performance parameters of kinematics and dynamic mechanisms, using inductive and incremental encoders, to a Mitsubishi Mechatronic System" "PN-II-IN-CI-2012-1-0389".

All these matters are copyrighted! Copyrights: 394-qodGnhhtej, from 17-02-2010 13:42:18; 463-vpstuCGsiy, from 20-03-2010 12:45:30; 631-sqfsgqvutm, from 24-05-2010 16:15:22; 933-CrDztEfqow, from 07-01-2011 13:37:52. 421-qDiazjHkBu, from 01-03-2010 22:49:44; 3679-vpqggvwrhm, from 04-01-2015 01:44:46; 1375-tnzjHFAqGF, from 02-092011 15:19:23; 398-tDGpbsxgrD, from 18-02-2010 01:16:36 and 394-qodGnhhtej, from 1702-2010 13:42:18.

\section{ETHICS}

Authors should address any ethical issues that may arise after the publication of this manuscript.

\section{REFERENCES}

AMORESANO, A.; AVAGLIANO, V.; NIOLA, V.; QUAREMBA, G. (2013) The Assessment of the in-Cylinder Pressure by Means of the Morpho-Dynamical Vibration Analysis - Methodology and Application, in IREME Journal, v. 7, n. 6, p. 999-1006. ANDERSON, R. B. (1984) The Fischer-Tropsch Synthesis, Academic Press. 
ANTONESCU, P.; PETRESCU, F. I. T. (1985) An analytical method of synthesis of cam mechanism and flat stick. Proceedings of the 4th International Symposium on Theory and Practice of Mechanisms, (TPM’ 89), Bucharest.

ANTONESCU, P.; PETRESCU, F. I. T. (1989) Contributions to kinetoplast dynamic analysis of distribution mechanisms. SYROM'89, Bucharest.

ANTONESCU, P.; OPREAN, M.; PETRESCU, F. I. T. (1985a) Contributions to the synthesis of oscillating cam mechanism and oscillating flat stick. Proceedings of the 4th International Symposium on Theory and Practice of Mechanisms, (TPM’ 85), Bucharest.

ANTONESCU, P.; OPREAN, M.; PETRESCU, F. I. T. (1985b) At the projection of the oscillate cams, there are mechanisms and distribution variables. Proceedings of the 5th Conference of Engines, Automobiles, Tractors and Agricultural Machines, (TAM' 58), I-Motors and Cars, Brasov.

ANTONESCU, P.; OPREAN, M.; PETRESCU, F. I. T. (1986) Projection of the profile of the rotating camshaft acting on the oscillating plate with disengagement. Proceedings of the 3rd National Computer-aided Design Symposium in the field of Mechanisms and Machine Parts, (MMP’ 86), Brasov.

ANTONESCU, P.; OPREAN, M.; PETRESCU, F. I. T. (1987) Dynamic analysis of the cam distribution mechanisms. Proceedings of the 7th National Symposium on Industrial Robots and Space Mechanisms, (RSM' 87), Bucharest.

ANTONESCU, P.; OPREAN, M.; PETRESCU, F. (1988) Analytical synthesis of Kurz profile, rotating the flat cam. Mach, Build. Rev.

ANTONESCU, P.; PETRESCU, F. I. T.; ANTONESCU, O. (1994) Contributions to the synthesis of the rotating cam mechanism and the tip of the balancing tip. Brasov.

ANTONESCU, P.; PETRESCU, F. I. T.; ANTONESCU, O. (1997) Geometrical synthesis of the rotary cam and balance tappet mechanism. Bucharest, n. 3, p. 23-23.

ANTONESCU, P.; PETRESCU, F. I. T.; ANTONESCU, O. (2000a) Contributions to the synthesis of the rotary disc-cam profile. Proceedings of the 8th International Conference on the Theory of Machines and Mechanisms, (TMM' 00), Liberec, Czech Republic, p. 5156.

ANTONESCU, P.; PETRESCU, F. I. T.; ANTONESCU, O. (2000b) Synthesis of the rotary cam profile with balance follower. Proceedings of the 8th Symposium on Mechanisms and Mechanical Transmissions, (MMT’00), Timişoara, p. 39-44.

ANTONESCU, P.; PETRESCU, F. I. T.; ANTONESCU, O. (2001) Contributions to the synthesis of mechanisms with rotary disc-cam. Proceedings of the 8th IFToMM International Symposium on Theory of Machines and Mechanisms, (TMM' 01), Bucharest, ROMANIA, p. 31-36.

ATEFI, G.;ABDOUS , M. A.; GANJEHKAVIRI, A. (2008) Analytical Solution of Temperature Field in Hollow Cylinder under Time Dependent Boundary Condition Using Fourier series, Am. J. Eng. Applied Sci., v. 1, n. 2, p. 141-148. DOI:

10.3844/ajeassp.2008.141.148

AVAEI, A.; GHOTBI, A. R.; ARYAFAR, M. (2008) Investigation of Pile-Soil Interaction Subjected to Lateral Loads in Layered Soils, Am. J. Eng. Applied Sci., v. 1, n. 1, p. 76-81. DOI: 10.3844 /ajeassp.2008.76.81 
AVERSA, R.; PETRESCU, R. V. V.; APICELLA, A.; PETRESCU, F. I. T. (2017a) Nanodiamond hybrid materials for structural biomedical application. Am. J. Biochem.

Biotechnol., n. 13, p. 34-41. DOI: 10.3844/ajbbsp.2017.34.41

AVERSA, R.; PETRESCU, R. V. V.; AKASH, B.; BUCINELL, R. B.; CORCHADO, J. M.; (2017b) Kinematics and forces to a new model forging manipulator. Am. J. Applied Sci., n. 14, p. 60-80. DOI: 10.3844/ajassp.2017.60.80

AVERSA, R.; PETRESCU, R. V. V.; APICELLA, A.; PETRESCU, F. I. T.; CALAUTIT, J. K. (2017c) Something about the V engines design. Am. J. Applied Sci., n. 14, p. 34-52. DOI: 10.3844/ajassp.2017.34.52

AVERSA, R.; PARCESEPE, D.; PETRESCU, R. V. V.; BERTO, F.; CHEN, G. (2017d) Process ability of bulk metallic glasses. Am. J. Applied Sci., n. 14, p. 294-301. DOI: 10.3844/ajassp.2017.294.301

AVERSA, R.; PETRESCU, R. V. V.; AKASH, B.; BUCINELL, R. B.; CORCHADO, J. M. (2017e) Something about the balancing of thermal motors. Am. J. Eng. Applied Sci., n. 10, p. 200.217. DOI: 10.3844/ajeassp.2017.200.217

AVERSA, R.; PETRESCU, F. I. T.; PETRESCU, R. V. V.; APICELLA, A. (2016a) Biomimetic FEA bone modeling for customized hybrid biological prostheses development. Am. J. Applied Sci., n. 13, p. 1060-1067. DOI: 10.3844/ajassp.2016.1060.1067

AVERSA, R.; PARCESEPE, D.; PETRESCU, R. V. V.; CHEN, G.; PETRESCU, F. I. T. (2016b) Glassy amorphous metal injection molded induced morphological defects. Am. J. Applied Sci., n. 13, p. 1476-1482. DOI: 10.3844/ajassp.2016.1476.1482

AVERSA, R.; PETRESCU, R. V. V.; PETRESCU, F. I. T.; APICELLA, A. (2016c) Smartfactory: Optimization and process control of composite centrifuged pipes. Am. J. Applied Sci., n. 13, p. 1330-1341. DOI: 10.3844/ajassp.2016.1330.1341

AVERSA, R.; TAMBURRINO, F.; PETRESCU, R. V. V.; PETRESCU, F. I. T.; ARTUR, M. (2016d) Biomechanically inspired shape memory effect machines driven by muscle like acting NiTi alloys. Am. J. Applied Sci., n. 13, p. 1264-1271. DOI: 10.3844/ajassp.2016.1264.1271

AVERSA, R.; BUZEA, E. M.; PETRESCU, R. V. V.; APICELLA, A.; NEACSA, M. (2016e) Present a mechatronic system having able to determine the concentration of carotenoids. Am. J. Eng. Applied Sci., n. 9, p. 1106-1111. DOI:

10.3844/ajeassp.2016.1106.1111

AVERSA, R.; PETRESCU, R. V. V.; R. SORRENTINO, PETRESCU, F. I. T.; APICELLA, A. (2016f) Hybrid ceramo-polymeric nanocomposite for biomimetic scaffolds design and preparation. Am. J. Eng. Applied Sci., n. 9, p. 1096-1105. DOI:

10.3844/ajeassp.2016.1096.1105

AVERSA, R.; PERROTTA, V.; PETRESCU, R. V. V.; MISIANO, C.; PETRESCU, F. I. T. (2016g) From structural colors to super-hydrophobicity and achromatic transparent protective coatings: Ion plating plasma assisted $\mathrm{TiO}_{2}$ and $\mathrm{SiO}_{2}$ nano-film deposition. Am. J. Eng.

Applied Sci., n. 9, p. 1037-1045. DOI: 10.3844/ajeassp.2016.1037.1045

AVERSA, R.; PETRESCU, R. V. V.; PETRESCU, F. I. T.; APICELLA, A. (2016h)

Biomimetic and evolutionary design driven innovation in sustainable products development.

Am. J. Eng. Applied Sci., n. 9, p. 1027-1036. DOI: 10.3844/ajeassp.2016.1027.1036 
DOI: 10.14807/ijmp.v11i3.930

AVERSA, R.; PETRESCU, R. V. V.; APICELLA, A.; PETRESCU, F. I. T. (2016i)

Mitochondria are naturally micro robots - a review. Am. J. Eng. Applied Sci., n. 9, p. 991-1002. DOI: 10.3844/ajeassp.2016.991.1002

AVERSA, R.; PETRESCU, R. V. V.; APICELLA, A.; PETRESCU, F. I. T. (2016j) We are addicted to vitamins C and E-A review. Am. J. Eng. Applied Sci., n. 9, p. 1003-1018. DOI: 10.3844/ajeassp.2016.1003.1018

AVERSA, R.; PETRESCU, R. V. V.; APICELLA, A.; PETRESCU, F. I. T. (2016k)

Physiologic human fluids and swelling behavior of hydrophilic biocompatible hybrid ceramopolymeric materials. Am. J. Eng. Applied Sci., n. 9, p. 962-972. DOI:

10.3844/ajeassp.2016.962.972

AVERSA, R.; PETRESCU, R. V. V.; APICELLA, A.; PETRESCU, F. I. T. (2016l) One can slow down the aging through antioxidants. Am. J. Eng. Applied Sci., n. 9, p. 1112-1126. DOI: 10.3844/ajeassp.2016.1112.1126

AVERSA, R.; PETRESCU, R. V. V.; APICELLA, A.; PETRESCU, F. I. T. (2016m) About homeopathy or «Similia Similibus Curentur». Am. J. Eng. Applied Sci., n. 9, p. 11641172. DOI: $10.3844 /$ ajeassp.2016.1164.1172

AVERSA, R.; PETRESCU, R. V. V.; APICELLA, A.; PETRESCU, F. I. T. (2016n) The basic elements of life's. Am. J. Eng. Applied Sci., n. 9, p. 1189-1197. DOI:

10.3844/ajeassp.2016.1189.1197

AVERSA, R.; PETRESCU, F. I. T.; PETRESCU, R. V. V.; APICELLA, A. (2016o) Flexible stem trabecular prostheses. Am. J. Eng. Applied Sci., n. 9, p. 1213-1221. DOI:

10.3844/ajeassp.2016.1213.122

AZAGA, M.; OTHMAN, M. (2008) Source Couple Logic (SCL, p. Theory and Physical Design, Am. J. Eng. Applied Sci., v. 1, n. 1, p. 24-32. DOI: 10.3844/ajeassp.2008.24.32

BISHOP J. L. H. (1950-51) An analytical approach to automobile valve gear design. Inst. of Mech. Engrs. Auto-Division Proc. 4, p. 150-160.

CAO, W.; DING, H.; BIN, Z.; ZIMING, C. (2013) New structural representation and digitalanalysis platform for symmetrical parallel mechanisms. Int. J. Adv. Robotic Sys. DOI: $10.5772 / 56380$

CHOI J. K.; KIM S. C. (1994) Hyundai Motor Co. Korea, An Experimental Study on the Frictional Characteristics in the Valve Train System. (945046), In FISITA CONGRESS, p. 17-21, Beijing, p. 374-380.

COMAnescu, A. (2010) Bazele Modelarii Mecanismelor. 1st Edn.; E. Politeh, Press, Bucureşti, p. 274.

DE FALCO, D.; DI MASSA, G.; PAGANO, S.; STRANO, S. (2013a) Motorcycle Handlebar Dynamic Response: Theoretical and Experimental Investigation, in IREME Journal, v. 7, n. 5, p. 795-801.

DE FALCO, D.; DI MASSA, G.; PAGANO, S. (2013b) A Full Scale Motorcycle Dynamic Rig, in IREME Journal, v. 7, n. 3, p. 519-526.

DONG, H.; GIAKOUMIDIS, N.; FIGUEROA, N.; MAVRIDIS, N. (2013) Approaching behaviour monitor and vibration indication in developing a General Moving Object Alarm System (GMOAS). Int. J. Adv. Robotic Sys. DOI: 10.5772/56586

YOUSIF EL-TOUS, (2008) Pitch Angle Control of Variable Speed Wind Turbine, Am. J. Eng. Applied Sci., v. 1, n. 2, p. 118-120. DOI: 10.3844/ajeassp.2008.118.120 
DOI: 10.14807/ijmp.v11i3.930

FRANKLIN, D. J. (1930) Ingenious Mechanisms for Designers and Inventors. 1st Edn.; Industrial Press Publisher.

GANAPATHI, P.; ROBINSON, Y. (2013) Experimental Investigation on the Performance, Emission and Combustion Characteristics of a Diesel Engine Fuelled with Polymer Oil - Ethanol Blends, in IREME Journal, v. 7, n. 5, July 2013, p. 919-924.

HE, B.; WANG, Z.; LI, Q.; XIE, H.; SHEN, R. (2013) An analytic method for the kinematics and dynamics of a multiple-backbone continuum robot. IJARS. DOI: 10.5772/54051

HEYWOOD, J. B. (1988) Internal Combustion Engine Fundamentals, McGraw-Hill.

HRONES J. A. (1948) An analysis of Dynamic Forces in a Cam-Driver System, Trans. ASME, v. 70, p. 473-482.

JOLGAF, M.; SULAIMAN, S. B.; ARIFFIN, M. K. A.; FAIEZA, A. A. (2008) Closed Die Forging Geometrical Parameters Optimization for Al-MMC, Am. J. Eng. Applied Sci., v. 1, n. 1, p. 1-6. DOI : 10.3844/ajeassp.2008.1.6

KANNAPPAN, A. N.; KESAVASAMY, R.; PONNUSWAMY, V. (2008) Molecular Interaction Studies of H-Bonded Complexes of Benzamide in 1,4-Dioxan with Alcohols From Acoustic and Thermodynamic Parameters, Am. J. Eng. Applied Sci., v. 1, n. 2, p. 9599. DOI: 10.3844/ajeassp.2008.95.99

KARIKALAN, L.; CHANDRASEKARAN, M.; SUDHAGAR, K. (2013) Comparative Studies on Vegetable Oil Usage in CI Engines as an Alternative to Diesel Fuel, in IREME Journal, V. 7, N. 4, May 2013, p. 705-715.

LEE, B. J. (2013) Geometrical derivation of differential kinematics to calibrate model parameters of flexible manipulator. Int. J. Adv. Robotic Sys. DOI: 10.5772/55592

LEIDEL, J. A. (1997) An Optimized Low Heat Rejection Engine for Automotive Use, SAE paper No. 970068, 1997.

LIN, W.; LI, B.; YANG, X.; ZHANG, D. (2013) Modelling and control of inverse dynamics for a 5-DOF parallel kinematic polishing machine. Int. J. Adv. Robotic Sys. DOI: $10.5772 / 54966$

LIU, H.; ZHOU, W.; LAI, X.; ZHU, S. (2013) An efficient inverse kinematic algorithm for a PUMA560-structured robot manipulator. IJARS. DOI: 10.5772/56403

MAHALINGAM, S.; RAMESH BAPU, B. R. (2013) Experimental and Emission Analysis of Rubber Seed Oil and Jatropha Oil Blends with Diesel in Compression Ignition Engine, in IREME Journal, v. 7, n. 5, p. 955-959.

MEENA, P.; RITTIDECH, S. (2008) Comparisons of Heat Transfer Performance of a Closed-looped Oscillating Heat Pipe and Closed-looped Oscillating Heat Pipe with Check Valves Heat Exchangers, Am. J. Eng. Applied Sci., v. 1, n. 1, p. 7-11. DOI: 10.3844/ajeassp.2008.7.11

MEENA, P.; RITTIDECH, S.; TAMMASAENG, P. (2008) Effect of Inner Diameter and Inclination Angles on Operation Limit of Closed-Loop Oscillating Heat-Pipes with Check Valves, Am. J. Eng. Applied Sci., v. 1, n. 2, p. 100-103. DOI: 10.3844/ajeassp.2008.100.103 MIRSAYAR, M.M.; JONEIDI, V. A.; PETRESCU, R. V. V.; PETRESCU, F. I. T.; BERTO, F. (2017) Extended MTSN criterion for fracture analysis of soda lime glass. Eng. Fracture Mechan., n. 178, p. 50-59. DOI: 10.1016/j.engfracmech.2017.04.018 
NAIMA, K.; LIAZID, A. (2013) Numerical Investigation on Combustion Behaviors of Direct-Injection Spark Ignition Engine Fueled with CNG-Hydrogen Blends, in IREME Journal, v. 7, n. 4, p. 652-663.

NARASIMAN, V.; JEYAKUMAR, S.; MANI, M. (2013) Optimizing the Compression Ratio of C.I. Engine Fuelled in Sardine Oil Ethyl Ester, in IREME Journal, v. 7, n. 3, p. 463-467.

NG, K. C.; YUSOFF, M. Z.; MUNISAMY, K.; HASINI, H.; SHUAIB, N. H. (2008) TimeMarching Method for Computations of High-Speed Compressible Flow on Structured and Unstructured Grid, Am. J. Eng. Applied Sci., v. 1, n. 2, p. 89-94. DOI: 10.3844/ajeassp.2008.89.94

PADULA, F.; PERDEREAU, V. (2013) An on-line path planner for industrial manipulators. Int. J. Adv. Robotic Sys. DOI: 10.5772/55063

PANNIRSELVAM, N.; RAGHUNATH, P. N.; SUGUNA, K. (2008) Neural Network for Performance of Glass Fibre Reinforced Polymer Plated RC Beams, Am. J. Eng. Applied Sci., v. 1, n. 1, p. 82-88. DOI: 10.3844/ajeassp.2008.82.88

PERUMAAL, S.; JAWAHAR, N. (2013) Automated trajectory planner of industrial robot for pick-and-place task. IJARS. DOI: 10.5772/53940

PETRESCU, F. I. T.; PETRESCU, R. (1995a) Contributions to optimization of the polynomial motion laws of the stick from the internal combustion engine distribution mechanism. Bucharest, n. 1, p. 249-256.

PETRESCU, F. I. T.; PETRESCU, R. (1995b) Contributions to the synthesis of internal combustion engine distribution mechanisms. Bucharest, n. 1, p. 257-264.

PETRESCU, F. I. T.; PETRESCU, R. (1997a) Dynamics of cam mechanisms (exemplified on the classic distribution mechanism). Bucharest, n. 3, p. 353-358.

PETRESCU, F. I. T.; PETRESCU, R. (1997b) Contributions to the synthesis of the distribution mechanisms of internal combustion engines with a Cartesian coordinate method. Bucharest, n. 3, p. 359-364.

PETRESCU, F. I. T.; PETRESCU, R. (1997c) Contributions to maximizing polynomial laws for the active stroke of the distribution mechanism from internal combustion engines.

Bucharest, n. 3, p. 365-370.

PETRESCU, F. I. T.; PETRESCU, R. (2000a) Synthesis of distribution mechanisms by the rectangular (Cartesian) coordinate method. Proceedings of the 8th National Conference on International Participation, (CIP' 00), Craiova, Romania, p. 297-302.

PETRESCU, F. I. T.; PETRESCU, R. (2000b). The design (synthesis) of cams using the polar coordinate method (triangle method). Proceedings of the 8th National Conference on International Participation, (CIP' 00), Craiova, Romania, p. 291-296.

PETRESCU, F. I. T.; PETRESCU, R. (2002a) Motion laws for cams. Proceedings of the International Computer Assisted Design, National Symposium Participation, (SNP' 02), Braşov, p. 321-326.

PETRESCU, F. I. T.; PETRESCU, R. (2002b) Camshaft dynamics elements. Proceedings of the International Computer Assisted Design, National Participation Symposium, (SNP' 02), Braşov, p. 327-332.

PETRESCU, F. I. T.; PETRESCU, R. (2003) Some elements regarding the improvement of the engine design. Proceedings of the National Symposium, Descriptive Geometry, Technical Graphics and Design, (GTD' 03), Braşov, p. 353-358. 
PETRESCU, F. I. T.; PETRESCU, R. (2005a) The cam design for a better efficiency. Proceedings of the International Conference on Engineering Graphics and Design, (EGD’ 05), Bucharest, p. 245-248.

PETRESCU, F. I. T.; PETRESCU, R. (2005b) Contributions at the dynamics of cams. Proceedings of the 9th IFToMM International Symposium on Theory of Machines and Mechanisms, (TMM’ 05), Bucharest, Romania, p. 123-128.

PETRESCU, F. I. T.; PETRESCU, R. (2005c) Determining the dynamic efficiency of cams. Proceedings of the 9th IFToMM International Symposium on Theory of Machines and Mechanisms, (TMM’ 05), Bucharest, Romania, p. 129-134.

PETRESCU, F. I. T.; PETRESCU, R. (2005d) An original internal combustion engine. Proceedings of the 9th IFToMM International Symposium on Theory of Machines and Mechanisms, (TMM’ 05), Bucharest, Romania, p. 135-140.

PETRESCU, F. I. T.; PETRESCU, R. (2005e) Determining the mechanical efficiency of Otto engine's mechanism. Proceedings of the 9th IFToMM International Symposium on Theory of Machines and Mechanisms, (TMM 05), Bucharest, Romania, p. 141-146.

PETRESCU, F. I. T.; PETRESCU, R. V. V. (2011a) Dinamica mecanismelor de distributie, Create Space publisher, USA, ISBN 978-1-4680-5265-7, 188 pages, Romanian version.

PETRESCU, F. I. T.; PETRESCU, R. (2011b) Mechanical Systems, Serial and Parallel (Romanian). 1st Edn.; LULU Publisher, London, UK, p. 124.

PETRESCU, F. I. T.; PETRESCU, R. (2011c) Trenuri Planetare. Createspace Independent Pub.; 104 pages, ISBN-13: 978-1468030419.

PETRESCU, F. I. T.; PETRESCU, R. (2012a) Kinematics of the planar quadrilateral mechanism. ENGEVISTA, n. 14, p. 345-348.

PETRESCU, F. I. T.; PETRESCU, R. (2012b) Mecatronica-Sisteme Seriale si Paralele. 1st Edn.; Create Space Publisher, USA, p. 128.

PETRESCU, F. I. T.; PETRESCU, R. V. (2013a) An Algorithm for Setting the Dynamic Parameters of the Classic Distribution Mechanism, In IREMOS Journal, ISSN: 1974-9821, v. 6, n. 5, Part B, p. 1637-1641.

PETRESCU, F. I. T.; PETRESCU, R. V. (2013b) Dynamic Synthesis of the Rotary Cam and Translated Tappet with Roll, In IREMOS Journal, ISSN: 1974-9821, v. 6, n. 2, Part B, April 2013, p. 600-607.

PETRESCU, F. I. T.; PETRESCU, R. V. (2013c) Forces and Efficiency of Cams, in IREME, v. 7, n. 3, p. 507-511.

PETRESCU, F. I. T.; PETRESCU, R. V. (2013d) Cams with High Efficiency, in IREME, v. 7, n. 4, p. 599-606.

PETRESCU, F. I. T.; PETRESCU, R. (2013e) Cinematics of the 3R dyad. ENGEVISTA, n. 15, p. 118-124.

PETRESCU, F. I. T.; PETRESCU, R. V. (2014) Cam Gears Dynamics in the Classic Distribution. In Independent Journal of Management \& Production, ISSN: 2236-269X, v. 5, n. 1, p. 166-185.

PETRESCU, F. I. T.; PETRESCU, R. (2016a) Parallel moving mechanical systems kinematics. ENGEVISTA, n. 18, p. 455-491. 
PETRESCU, F. I. T.; PETRESCU, R. (2016b) Direct and inverse kinematics to the anthropomorphic robots. ENGEVISTA, n. 18, p. 109-124.

PETRESCU, F. I. T.; PETRESCU, R. (2016c) Dynamic cinematic to a structure 2R. Revista Geintec-Gestao Inovacao E Tecnol., n. 6, p. 3143-3154.

PETRESCU, R. V.; AVERSA, R.; APICELLA, A.; PETRESCU, F. I. T. (2016) Future medicine services robotics. Am. J. Eng. Applied Sci., n. 9, p. 1062-1087. DOI: 10.3844/ajeassp.2016.1062.1087

PETRESCU, F. I. T.; GRECU, B.; COMANESCU, A.; PETRESCU, R. V. V. (2009) Some mechanical design elements. Proceeding of the International Conference on

Computational Mechanics and Virtual Engineering, (MVE' 09), Braşov, p. 520-525.

PETRESCU, F. I. T. (2011) Teoria Mecanismelor si a Masinilor: Curs Si Aplicatii. 1st Edn.; CreateSpace Independent Publishing Platform. ISBN-10: 1468015826. P. 432.

PETRESCU, F. I. T. (2012a) Bazele analizei și optimizării sistemelor cu memorie rigidă curs și aplicații, Create Space publisher, USA, 2012, ISBN 978-1-4700-2436-9, 164 pages, Romanian edition.

PETRESCU, F. I. T. (2012b) Teoria mecanismelor - Curs si aplicatii (editia a doua), Create Space publisher, USA, September 2012, ISBN 978-1-4792-9362-9, 284 pages, Romanian version.

PETRESCU, F. I. T. (2015a) Geometrical synthesis of the distribution mechanisms. Am. J. Eng. Applied Sci., n. 8, p. 63-81. DOI: 10.3844/ajeassp.2015.63.81

PETRESCU, F. I. T. (2015b) Machine motion equations at the internal combustion heat engines. Am. J. Eng. Applied Sci., n. 8, p. 127-137. DOI: 10.3844/ajeassp.2015.127.137

PETRESCU, R. V.; AVERSA, R.; AKASH, B.; BUCINELL, R.; CORCHADO, J. (2017) Yield at thermal engines internal combustion. Am. J. Eng. Applied Sci., n. 10, p. 243-251. DOI: 10.3844/ajeassp.2017.243.251

PETRESCU, R. V.; AVERSA, R.; AKASH, B.; RONALD, B.; CORCHADO, J. (2017b) Velocities and accelerations at the 3R mechatronic systems. Am. J. Eng. Applied Sci., n. 10, p. 252-263. DOI: 10.3844/ajeassp.2017.252.263

PETRESCU, R. V.; AVERSA, R.; AKASH, B.; BUCINELL, R.; CORCHADO, J. (2017c) Anthropomorphic solid structures n-r kinematics. Am. J. Eng. Applied Sci., n. 10, p. 279291. DOI: 10.3844/ajeassp.2017.279.291

PETRESCU, R. V.; AVERSA, R.; AKASH, B.; BUCINELL, R.; CORCHADO, J. (2017d) Inverse kinematics at the anthropomorphic robots, by a trigonometric method. Am. J. Eng. Applied Sci., n. 10, p. 394-411. DOI: 10.3844/ajeassp.2017.394.411

PETRESCU, R. V.; AVERSA, R.; AKASH, B.; BUCINELL, R.; CORCHADO, J. (2017e). Forces at internal combustion engines. Am. J. Eng. Applied Sci., n. 10, p. 382-393. DOI: 10.3844/ajeassp.2017.382.393

PETRESCU, R. V.; AVERSA, R.; AKASH, B.; BUCINELL, R.; CORCHADO, J. (2017f) Gears-Part I. Am. J. Eng. Applied Sci., n. 10, p. 457-472. DOI:

10.3844/ajeassp.2017.457.472

PETRESCU, R. V.; AVERSA, R.; AKASH, B.; BUCINELL, R.; CORCHADO, J. (2017g)

Gears-part II. Am. J. Eng. Applied Sci., n. 10, p. 473-483. DOI:

10.3844/ajeassp.2017.473.483 
PETRESCU, R. V.; AVERSA, R.; AKASH, B.; BUCINELL, R.; CORCHADO, J. (2017h) Cam-gears forces, velocities, powers and efficiency. Am. J. Eng. Applied Sci., n. 10, p. 491-505. DOI: 10.3844/ajeassp.2017.491.505

PETRESCU, R. V.; AVERSA, R.; AKASH, B.; BUCINELL, R.; CORCHADO, J. (2017i) Dynamics of mechanisms with cams illustrated in the classical distribution. Am. J. Eng. Applied Sci., n. 10, p. 551-567. DOI: 10.3844/ajeassp.2017.551.567

PETRESCU, R. V.; AVERSA, R.; AKASH, B.; BUCINELL, R.; CORCHADO, J. (2017j) Testing by non-destructive control. Am. J. Eng. Applied Sci., n. 10, p. 568-583. DOI: 10.3844/ajeassp.2017.568.583

PETRESCU, R. V.; AVERSA, R.; APICELLA, A.; PETRESCU, F. I. T. (2017k)

Transportation engineering. Am. J. Eng. Applied Sci., n. 10, p. 685-702. DOI: 10.3844/ajeassp.2017.685.702

PETRESCU, R. V.; AVERSA, R.; KOZAITIS, S.; APICELLA, A.; PETRESCU, F. I. T.; (2017l) The quality of transport and environmental protection, part I. Am. J. Eng. Applied Sci., n. 10, p. 738-755. DOI: 10.3844/ajeassp.2017.738.755

PETRESCU, R. V.; AVERSA, R.; AKASH, B.; BUCINELL, R.; CORCHADO, J. (2017m0 Modern propulsions for aerospace-a review. J. Aircraft Spacecraft Technol., n. 1, p. 1-8. DOI: $10.3844 /$ jastsp.2017.1.8

PETRESCU, R. V.; AVERSA, R.; AKASH, B.; BUCINELL, R.; CORCHADO, J. (2017n) Modern propulsions for aerospace-part II. J. Aircraft Spacecraft Technol., n. 1, p. 9-17. DOI: $10.3844 /$ jastsp.2017.9.17

PETRESCU, R. V.; AVERSA, R.; AKASH, B.; BUCINELL, R.; CORCHADO, J. (2017º) History of aviation-a short review. J. Aircraft Spacecraft Technol., n. 1, p. 30-49. DOI: 10.3844/jastsp.2017.30.49

PETRESCU, R. V.; AVERSA, R.; AKASH, B.; BUCINELL, R.; CORCHADO, J. (2017p) Lockheed martin-a short review. J. Aircraft Spacecraft Technol., n. 1, p. 50-68. DOI: 10.3844/jastsp.2017.50.68

PETRESCU, R. V.; AVERSA, R.; AKASH, B.; CORCHADO, J.; BERTO, F. (2017q) Our universe. J. Aircraft Spacecraft Technol., n. 1, p. 69-79. DOI: 10.3844/jastsp.2017.69.79

PETRESCU, R. V.; AVERSA, R.; AKASH, B.; CORCHADO, J.; BERTO, F. (2017r) What is a UFO? J. Aircraft Spacecraft Technol., n. 1, p. 80-90. DOI: 10.3844/jastsp.2017.80.90

PETRESCU, R. V.; AVERSA, R.; AKASH, B.; CORCHADO, J.; BERTO, F. (2017s) About bell helicopter FCX-001 concept aircraft-a short review. J. Aircraft Spacecraft Technol., n. 1, p. 91-96. DOI: 10.3844/jastsp.2017.91.96

PETRESCU, R. V.; AVERSA, R.; AKASH, B.; CORCHADO, J.; BERTO, F. (2017t) Home at airbus. J. Aircraft Spacecraft Technol., n. 1, p. 97-118. DOI: 10.3844/jastsp.2017.97.118

PETRESCU, R. V.; AVERSA, R.; AKASH, B.; CORCHADO, J.; BERTO, F. (2017u)

Airlander. J. Aircraft Spacecraft Technol., n. 1, p. 119-148. DOI:

10.3844/jastsp.2017.119.148

PETRESCU, R. V.; AVERSA, R.; AKASH, B.; CORCHADO, J.; BERTO, F. (2017v) When boeing is dreaming-a review. J. Aircraft Spacecraft Technol., n. 1, p. 149-161. DOI: 10.3844/jastsp.2017.149.161 
PETRESCU, R. V.; AVERSA, R.; AKASH, B.; CORCHADO, J.; BERTO, F. (2017w) About Northrop Grumman. J. Aircraft Spacecraft Technol., n. 1, p. 162-185. DOI: 10.3844/jastsp.2017.162.185

PETRESCU, R. V.; AVERSA, R.; AKASH, B.; CORCHADO, J.; BERTO, F. (2017x) Some special aircraft. J. Aircraft Spacecraft Technol., n. 1, p. 186-203. DOI:

10.3844/jastsp.2017.186.203

PETRESCU, R. V.; AVERSA, R.; AKASH, B.; CORCHADO, J.; BERTO, F. (2017y) About helicopters. J. Aircraft Spacecraft Technol., n. 1, p. 204-223. DOI:

10.3844/jastsp.2017.204.223

PETRESCU, R. V.; AVERSA, R.; AKASH, B.; BERTO, F.; APICELLA, A. (2017z) The modern flight. J. Aircraft Spacecraft Technol., n. 1, p. 224-233. DOI:

10.3844/jastsp.2017.224.233

PETRESCU, R. V.; AVERSA, R.; AKASH, B.; BERTO, F.; APICELLA, A. (2017aa)

Sustainable energy for aerospace vessels. J. Aircraft Spacecraft Technol. , n. 1, p. 234-240. DOI: 10.3844 /jastsp.2017.234.240

PETRESCU, R. V.; AVERSA, R.; AKASH, B.; BERTO, F.; APICELLA, A. (2017ab)

Unmanned helicopters. J. Aircraft Spacecraft Technol., n. 1, p. 241-248. DOI: 10.3844/jastsp.2017.241.248

PETRESCU, R. V.; AVERSA, R.; AKASH, B.; BERTO, F.; APICELLA, A. (2017ac) Project HARP. J. Aircraft Spacecraft Technol., n. 1, p. 249-257. DOI:

10.3844/jastsp.2017.249.257

PETRESCU, R. V.; AVERSA, R.; AKASH, B.; BERTO, F.; APICELLA, A. (2017ad) Presentation of Romanian engineers who contributed to the development of global aeronautics-part I. J. Aircraft Spacecraft Technol., n. 1, p. 258-271. DOI: 10.3844/jastsp.2017.258.271

PETRESCU, R. V.; AVERSA, R.; AKASH, B.; BERTO, F.; APICELLA, A. (2017ae) A first-class ticket to the planet mars, please. J. Aircraft Spacecraft Technol., n. 1, p. 272-281. DOI: $10.3844 /$ jastsp.2017.272.281

PETRESCU, R. V.; AVERSA, R.; APICELLA, A.; MIRSAYAR, M. M.; KOZAITIS, S. (2018a) NASA started a propeller set on board voyager 1 after 37 years of break. Am. J. Eng. Applied Sci. , n. 11, p. 66-77. DOI: 10.3844/ajeassp.2018.66.77

PETRESCU, R. V.; AVERSA, R.; APICELLA, A.; MIRSAYAR, M. M.; KOZAITIS, S. (2018b) There is life on mars? Am. J. Eng. Applied Sci. , n. 11, p. 78-91. DOI: 10.3844/ajeassp.2018.78.91

PETRESCU, R. V.; AVERSA, R.; APICELLA, A.; PETRESCU, F. I. T. (2018c) Friendly environmental transport. Am. J. Eng. Applied Sci. , n. 11, p. 154-165. DOI:

10.3844/ajeassp.2018.154.165

PETRESCU, R. V.; AVERSA, R.; AKASH, B.; ABU-LEBDEH, T. M.; APICELLA, A. (2018d) Buses running on gas. Am. J. Eng. Applied Sci. , n. 11, p. 186-201. DOI: 10.3844/ajeassp.2018.186.201

PETRESCU, R. V.; AVERSA, R.; AKASH, B.; ABU-LEBDEH, T. M.; APICELLA, A. (2018e) Some aspects of the structure of planar mechanisms. Am. J. Eng. Applied Sci., n. 11, p. 245-259. DOI: 10.3844/ajeassp.2018.245.259 
DOI: 10.14807/ijmp.v11i3.930

PETRESCU, R. V.; AVERSA, R.; ABU-LEBDEH, T. M.; APICELLA, A.; PETRESCU, F. I. T. (2018f) The forces of a simple carrier manipulator. Am. J. Eng. Applied Sci., n. 11, p. 260-272. DOI: 10.3844/ajeassp.2018.260.272

PETRESCU, R. V.; AVERSA, R.; ABU-LEBDEH, T. M.; APICELLA, A.; PETRESCU, F. I. T. (2018g) The dynamics of the otto engine. Am. J. Eng. Applied Sci., n. 11, p. 273-287. DOI: 10.3844/ajeassp.2018.273.287

PETRESCU, R. V.; AVERSA, R.; ABU-LEBDEH, T. M.; APICELLA, A.; PETRESCU, F. I. T. (2018h) NASA satellites help us to quickly detect forest fires. Am. J. Eng. Applied Sci., n. 11, p. 288-296. DOI: 10.3844/ajeassp.2018.288.296

PETRESCU, R. V.; AVERSA, R.; ABU-LEBDEH, T. M.; APICELLA, A.; PETRESCU, F. I. T. (2018i) Kinematics of a mechanism with a triad. Am. J. Eng. Applied Sci., n. 11, p. 297-308. DOI: 10.3844/ajeassp.2018.297.308

PETRESCU, R. V.; AVERSA, R.; APICELLA, A.; PETRESCU, F. I. T. (2018j) Romanian engineering "on the wings of the wind". J. Aircraft Spacecraft Technol. , n. 2, p. 1-18. DOI: 10.3844/jastsp.2018.1.18

PETRESCU, R. V.; AVERSA, R.; APICELLA, A.; PETRESCU, F. I. T. (2018k) NASA Data used to discover eighth planet circling distant star. J. Aircraft Spacecraft Technol., n. 2, p. 19-30. DOI: 10.3844 /jastsp.2018.19.30

PETRESCU, R. V.; AVERSA, R.; APICELLA, A.; PETRESCU, F. I. T. (2018l) NASA has found the most distant black hole. J. Aircraft Spacecraft Technol. , n. 2, p. 31-39. DOI: 10.3844/jastsp.2018.31.39

PETRESCU, R. V.; AVERSA, R.; APICELLA, A.; PETRESCU, F. I. T. (2018m) Nasa selects concepts for a new mission to titan, the moon of saturn. J. Aircraft Spacecraft Technol. , n. 2, p. 40-52. DOI: 10.3844/jastsp.2018.40.52

PETRESCU, R. V.; AVERSA, R.; APICELLA, A.; PETRESCU, F. I. T. (2018n) NASA sees first in 2018 the direct proof of ozone hole recovery. J. Aircraft Spacecraft Technol., n. 2, p. 53-64. DOI: 10.3844/jastsp.2018.53.64

POURMAHMOUD, N. (2008) Rarefied Gas Flow Modeling inside Rotating Circular Cylinder, Am. J. Eng. Applied Sci., v. 1, n. 1, p. 62-65. DOI: 10.3844/ajeassp.2008.62.65

RAHMANI, L.; DRAOUI, B.; BOUANINI, M.; BENACHOUR, E. (2013) CFD Study on Heat Transfer to Bingham Fluid During with Gate Impeller, in IREME, v. 7, n. 6, p. 10741079.

RAJASEKARAN, A.; RAGHUNATH, P. N.; SUGUNA, K. (2008) Effect of Confinement on the Axial Performance of Fibre Reinforced Polymer Wrapped RC Column, Am. J. Eng. Applied Sci., v. 1, n. 2, p. 110-117. DOI: 10.3844/ajeassp.2008.110.117

RAVI, S.; SUBRAMANIAN, R. (2013) Diesel Fuel Additives: an Overview, in IREME, v. 7, n. 4, p. 698-704.

RONNEY, P. D.; SHODA, M.; WAIDA, S. T.; DURBIN, E. J. (1994) Throttleless PremixedCharge Engines: Concept and Experiment, in Journal of Automobile Engineering, v. 208, p. 13-24.

SAPATE, K. D.; TIKEKAR, A. N. (2013) Engine Mapping for Improvement in Fuel Efficiency of Two Stroke SI Engine, in IREME, v. 7, n. 3, p. 392-394. 
DOI: 10.14807/ijmp.v11i3.930

SETHUSUNDARAM, P. P.; ARULSHRI, K. P.; MYLSAMY, K. (2013) Biodiesel Blend, Fuel Properties and its Emission Characteristics Sterculia Oil in Diesel Engine, in IREME, v. 7, n. 5, p. 925-929.

SHOJAEEFARD, M. H.; GOUDARZI, K.; NOORPOOR, A. R.; FAZELPOUR, M. (2008) A Study of Thermal Contact using Nonlinear System Identification Models, Am. J. Eng. Applied Sci., v. 1, n. 1, p. 16-23. DOI: 10.3844/ajeassp.2008.16.23

TAHER, S. A.; HEMATTI, R.; NEMATI, M. (2008) Comparison of Different Control Strategies in GA-Based Optimized UPFC Controller in Electric Power Systems, Am. J. Eng. Applied Sci., v. 1, n. 1, p. 45-52. DOI: 10.3844/ajeassp.2008.45.52

TAVALLAEI, M. A.; TOUSI, B. (2008) Closed Form Solution to an Optimal Control Problem by Orthogonal Polynomial Expansion, Am. J. Eng. Applied Sci., v. 1, n. 2, p. 104109. DOI: 10.3844 /ajeassp.2008.104.109

THEANSUWAN, W.; TRIRATANASIRICHAI, K. (2008) Air Blast Freezing of Lime Juice: Effect of Processing Parameters, Am. J. Eng. Applied Sci., v. 1, n. 1, p. 33-39. DOI: 10.3844/ajeassp.2008.33.39

ZAHARI, I.; ABRAS, M. A.; MAT ARISHAD, N. I.; ZAINAL, S. F.; MUHAMAD, M. F. (2013) Experimental Study to Identify Common Engine Part Load Conditions between Malaysian City Driving and NEDC Test, in IREME, v. 7, n. 6, p. 1152-1158.

ZAHEDI, S. A.; VAEZI, M.; TOLOU, N. (2008) Nonlinear Whitham-Broer-Kaup Wave Equation in an Analytical Solution, Am. J. Eng. Applied Sci., v. 1, n. 2, p. 161-167. DOI: 10.3844/ajeassp.2008.161.167

ZHU, G. et al. (2007) Closed-Loop Ignition Timing Control for SI Engines Using Ionization Current Feedback, IEEE Trans on Control Systems, p. 416-427.

ZULKIFLI, R.; SOPIAN, K.; ABDULLAH, S.; TAKRIFF, M. S. (2008) Effect of Pulsating Circular Hot Air Jet Frequencies on Local and Average Nusselt Number, Am. J. Eng.

Applied Sci., v. 1, n. 1, p. 57-61. DOI: 10.3844/ajeassp.2008.57.61 